\title{
Important soil parameters for evaluating tillage practices in the United States ${ }^{1}$
}

\author{
W. E. LARSON 2
}

\begin{abstract}
Soil parameters important in tillage practices for row crops are discussed for the seedling environment soil zone (row zone) and for the water management soil zone (intra-row zone). Mulches of crop residues, and ridge-furrow systems materially influenced the temperature of the soil. The optimum soil temperature at the $10 \mathrm{~cm}$ depth for maize growth early in the season was $23.3^{\circ} \mathrm{C}$. If the soil temperature was materially below the optimum, slight changes in soil temperature due to tillage practice markedly affected the growth of maize early in the season. The secondary aggregate size and compacting pressure around the seed and seedling root influence the total porosity and the size of the inter- and intra-aggregate pores. The size of the inter- and intraaggregate pores, in turn, influence water relations in the soil. The size of the inter-aggregate pores is related to the area of soil solution-seed and soil solution-seedling root contact. The total water transmission rate across the interface is probably related to the area of contact. Emergence of seedlings is often superior when compaction pressures are applied at seed level rather than on the soil surface.

Tillage tools can be used to create various microrelief in the water management soil zone to aid in the management of water. The potential amount of water that can be temporarily stored in the microdepressions is termed depression storage. Increased porosity, due to loosening a soil by tillage, acts as a reservoir for temporary storage of water during an intense rain.
\end{abstract}

Tillage practices usually have their greatest influence on plant growth during the early growing season when germination and extension of the seedling root is taking place. Prior to planting the soil can be manipulated easiest to whatever conditions are desired.

In the United States of America most major tillage problems are concerned with crops grown in rows. In row crop tillage certain conditions must be created around the seed for germination and seedling root growth. The zone in the seed row has been termed the seedling environment zone (FIGURE 1). Conditions for aiding in water management can be created between the crop rows and this has been called the water management zone. Our research has been directed at defining the conditions desirable for the seed and seedling and for determining ways to manipulate the soil for water management. The following discussion will include a review of research in the United States for determining the desirable conditions in the seedling environment and water management zones. Most of the discussion will be concerned with tillage for maize.

1 Contribution from the Soil and Water Conservation Research Division, Agricultural Research Service, USDA, and the Iowa Agricultural and Home Economics Experiment Station, Ames, Iowa. Journal paper No. J-4453 of the Iowa Agricultural and Home Economics Experiment Station, Ames, Iowa. Project No. 1486/

2 Soil Scientist, USDA, ARS, Ames, Iowa, and Professor of Soils, Iowa State University, Ames, Iowa. 


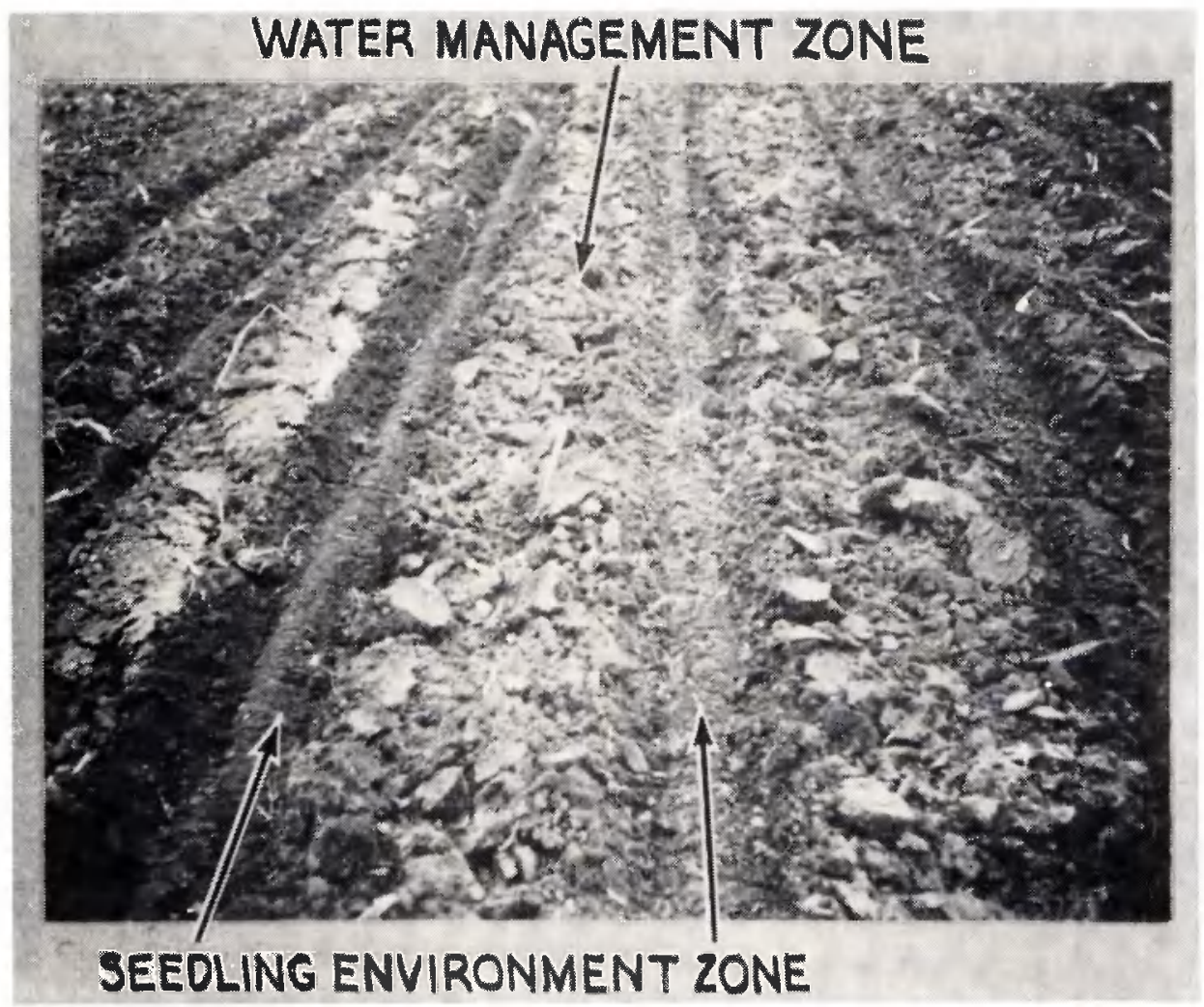

FIC. 1. The two soil zones as compared for row crops by tillage 


\section{SEEDLING ENVIRONMENT ZONE}

\section{Soil Temperature}

The temperature of the soil can be influenced by tillage practices through changes in the density and moisture content of the soil (5), the amount of mulch cover (3), and changes in the soil microrelief (2).

Tillage can influence the thermal properties of soil. According to VAN DuIN (5) loosening a soil decreases the heat capacity (expressed as $\mathrm{Cal} . \mathrm{cm}^{-3}\left({ }^{\circ} \mathrm{C}\right)^{-1}$ ) according to the following relation: $C_{b}=0.46 X_{v}+X_{w}$.

Where $\mathrm{C}^{\mathrm{b}}=$ the heat capacity of the soil, $\mathrm{X}_{\mathrm{v}}=$ the volume fraction of solids, and $\mathrm{X}_{\mathrm{w}}=$ the volume fraction of water. The thermal conductivity is decreased with decreasing volume fraction of solid (decreasing bulk density) and increased with increasing water contents. Loosening the soil often increases the amplitude of the daily temperature wave and retards the phase. The influence on the amplitude of the daily wave may amount to several degrees Centigrade. Tillage practices often influence soil temperature and consequently affect plant growth during the early part of the growing season.

In the United States of America, wind and water erosion protection are often obtained by leaving mulches of the previous crop residues on the soil surface during soil preparation for planting. The effect is presented in FIGURE 2 (3) of amounts of maize stover on the soil surface ranging from 0 to 18 metric tons per ha on the soil temperature at Ames, Iowa, at the $10 \mathrm{~cm}$ soil depth on a Webster silty clay loam soil for the growing season. In the experiment reported in FIGURE 2, maize was planted on May 1. During May and June, the crop did not shade a large por-

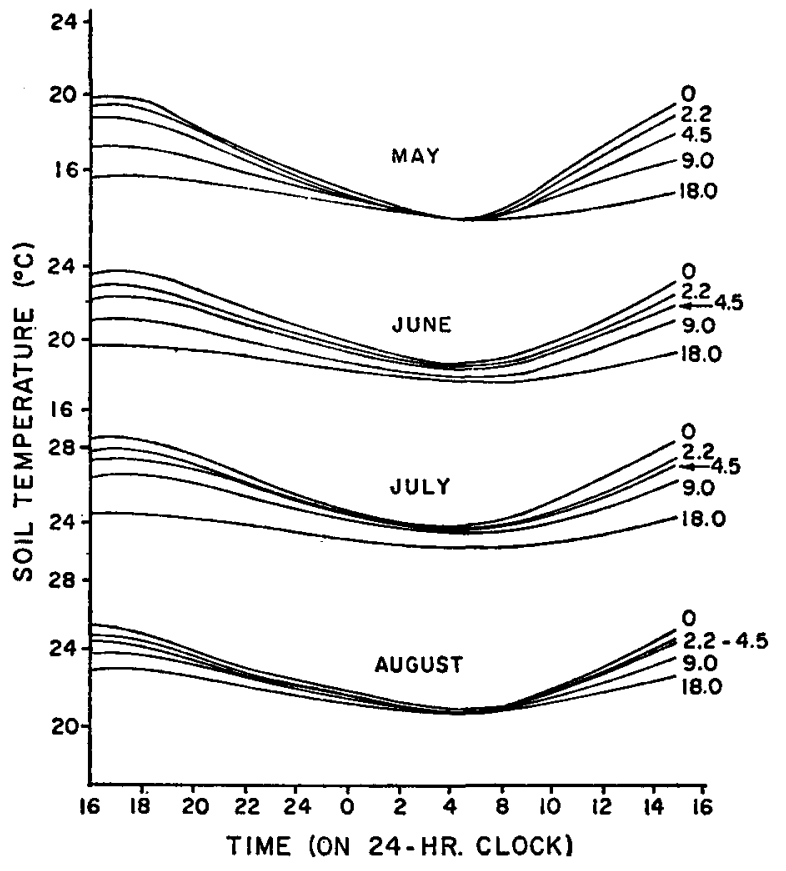

Neth. J. agric. Sci., Vol. 11 (1963) No. 2 Special Issue
FIG. 2.

Monthly average diurnal fluctuations of the $10 \mathrm{~cm}$ soil temperature as affected by amount corn stover mulch and time of season. The numbers to the right are the amounts of mulch in metric tons per hectare. 
tion of the soil, and, hence, the differences in soil temperature were largely a reflection of the amount of mulch. During August the maize crop shaded much of the soil surface thus minimizing the effect of the mulch. In this experiment, each 2 tons per ha of mulch applied over the practical range from 0 to 9 tons per ha reduced the average soil temperature during May and June at the $10 \mathrm{~cm}$ depth by about $0.4^{\circ} \mathrm{C}$. Increasing amounts of mulch progressively damped out the daily variation of temperature found in bare soil.

The soil temperature in the seed zone can be influenced materially by planting in ridges, in furrows, or in smooth microrelief. The data in FIGURE 3 (2) illustrate the daily temperature fluctuation in the seed zone as influenced by the microrelief on a clear day in May soon after planting of maize. At the time of maximum soil temperatures, the soil in the ridges at the $10 \mathrm{~cm}$ depth was about $1.4^{\circ} \mathrm{C}$ warmer than in the smooth microrelief and $2.8^{\circ} \mathrm{C}$ warmer than the soil in the furrows.

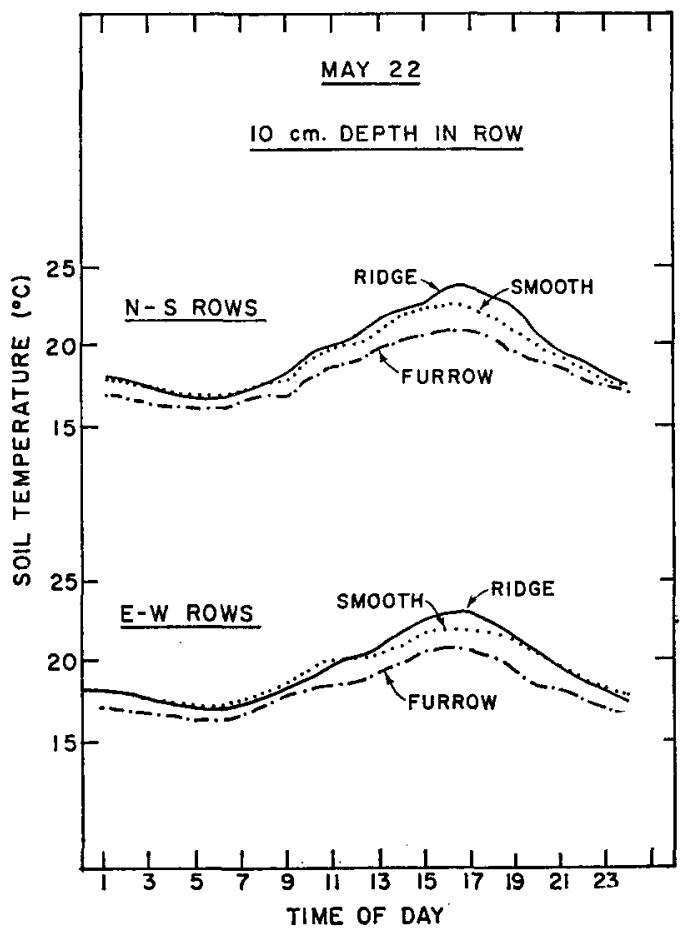

FIG. 3.

Diurnal course of soil temperature in the corn row at the $10 \mathrm{~cm}$ depth as affected by three tillage-induced microreliefs and by row direction

At the time of minimum temperature the soil in the furrows was about $0.5^{\circ} \mathrm{C}$ cooler than in the seed zone of the other two microreliefs. The time of day at which the maximum temperature was reached in the maize row was earliest for furrows, latest for ridges, and intermediate for smooth tillage (2). BuRrows (2) has presented the influence of microrelief and row direction on the soil temperature for various sites between $100 \mathrm{~cm}$ spaced maize rows at several times during the season.

These quantitative changes in average soil temperature, even though small, are nevertheless important because of the large changes in early growth of maize brought about by small changes in soil temperature regime. 
While tillage practices may influence soil temperature materially, changes in other soil properties usually accompany changes in soil temperature. To isolate the influence of soil temperature per se on maize growth, a technique for warming the soil with electric heating cables was used $(11,18)$. In experiment I (TABLE 1) conducted in 1955 at Ames, Iowa, the reduction in soil temperature produced by a

TABLE 1. Corn heights and yields as affected by mulching and heating the soil, Ames, Iowa, 1955 and 1957

\begin{tabular}{|c|c|c|c|c|c|c|c|c|}
\hline \multicolumn{5}{|c|}{ EXPERIMENT I (1955) } & \multicolumn{4}{|c|}{ EXPERIMENT II (1957) } \\
\hline & \multicolumn{2}{|c|}{$\begin{array}{l}\text { First } 31 \text { days } \\
\text { after planting }\end{array}$} & \multicolumn{2}{|c|}{$\begin{array}{l}\text { Entire } \\
\text { season }\end{array}$} & \multicolumn{2}{|c|}{$\begin{array}{l}\text { First } 40 \text { days } \\
\text { after planting }\end{array}$} & \multicolumn{2}{|c|}{$\begin{array}{l}\text { Entire } \\
\text { season }\end{array}$} \\
\hline & $\begin{array}{l}\text { Soil } \\
\text { temp. } \\
10 \mathrm{~cm} \\
\text { depth } \\
4 \text { P.M. }\end{array}$ & $\begin{array}{c}\text { Plant } \\
\text { height } \\
\text { June } 3 \\
1955\end{array}$ & $\begin{array}{l}\text { Soil } \\
\text { temp. } \\
\text { daily } \\
\text { ave. } \\
10 \mathrm{~cm} \\
\text { depth }\end{array}$ & $\begin{array}{l}\text { Grain } \\
\text { yield }\end{array}$ & $\begin{array}{l}\text { Soil } \\
\text { temp. } \\
\text { daily } \\
\text { ave. } \\
10 \mathrm{~cm} \\
\text { depth }\end{array}$ & $\begin{array}{c}\text { Plant } \\
\text { height } \\
\text { June 10 } \\
1957\end{array}$ & $\begin{array}{l}\text { Soil } \\
\text { temp. } \\
\text { daily } \\
\text { ave. } \\
10 \mathrm{~cm} \\
\text { depth }\end{array}$ & $\begin{array}{l}\text { Grain } \\
\text { yield }\end{array}$ \\
\hline Treatment & ${ }^{\circ} \mathrm{C}$ & $\mathrm{cm}$ & ${ }^{\circ} \mathrm{C}$ & ha & ${ }^{\circ} \mathrm{C}$ & cm & ${ }^{\circ} \mathbf{C}$ & ha \\
\hline 1. Mulch, unheated & 17,6 & 40,61 & 22,0 & 722 & 15,5 & 34,53 & 19,6 & 804 \\
\hline $\begin{array}{l}\text { 2. Bare, unheated . } \\
\text { 3. Bare, heated }\end{array}$ & 21,2 & 48,5 & 22,9 & 73 & 16,0 & 46,2 & 20,4 & 73 \\
\hline 4. Mulch, heated $\left(23.9^{\circ} \mathrm{C}\right) 5$ & 26,8 & 65,8 & 26,6 & 68 & 21,1 & 50,3 & 22,5 & 73 \\
\hline 5. Mulch, heated & 22,0 & 65,0 & 24,4 & 74 & 20,0 & 41,4 & 22,0 & 76 \\
\hline$\left(19.4 \& 23.9^{\circ} \mathrm{C}\right)^{6}$ & 25,2 & 69,8 & 23,4 & 80 & 21,6 & 49,0 & 22,6 & 72 \\
\hline
\end{tabular}

1 There is statistical significance at the $1 \%$ probability level between treatments 1 vs. 3,1 vs. 4 , 1 vs 5,2 vs. 3,2 vs. 4 and 2 vs. 5 and at the $5 \%$ probability level between 1 vs. 2 .

2 Statistically treatment 5 is significantly greater than all other treatments at the $5 \%$ level. All other comparisons not significant.

3 There is statistical significance at the $1 \%$ level between treatments 1 vs. 2,1 vs. 5 , and at the $5 \%$ level between 3 vs. 4,4 vs. 5 , and 1 vs. 4 .

4 No statistical significance at the $5 \%$ level.

5 Thermoregulator settings.

$619.4^{\circ} \mathrm{C}$ was the thermoregulator setting on experiment I and $23.9^{\circ} \mathrm{C}$ on experiment II.

mulch of $5600 \mathrm{~kg}$ per ha of oat straw was accompanied by a decrease in the rate of seedling emergence, and of growth during the early season and by a decrease in grain yield (11). A second experiment (TABLE 1) conducted in 1957 generally confirmed the results of experiment $I$ for growth early in the season.

Because of the location of the heating cables in the soil with respect to the temperature sensing element and because comparisons are made between heated and unheated soil, the temperatures shown in TABLE 1 may not be descriptive of the rhizosphere as a whole. They are of value for comparative purposes.

The soil moisture in experiment $I$ was kept near optimum and under these conditions, the depression in early growth caused by a mulch was rather completely overcome by heating the soil to a temperature comparable to unmulched soil. In experiment II, irrigation facilities were lacking, and, while heating a mulched soil appeared to overcome many of the deleterious influences of a mulch early in the season, soil moisture became the dominant limiting growth factor later in the season. Soil temperature throughout the season was inversely related to soil moisture, and 


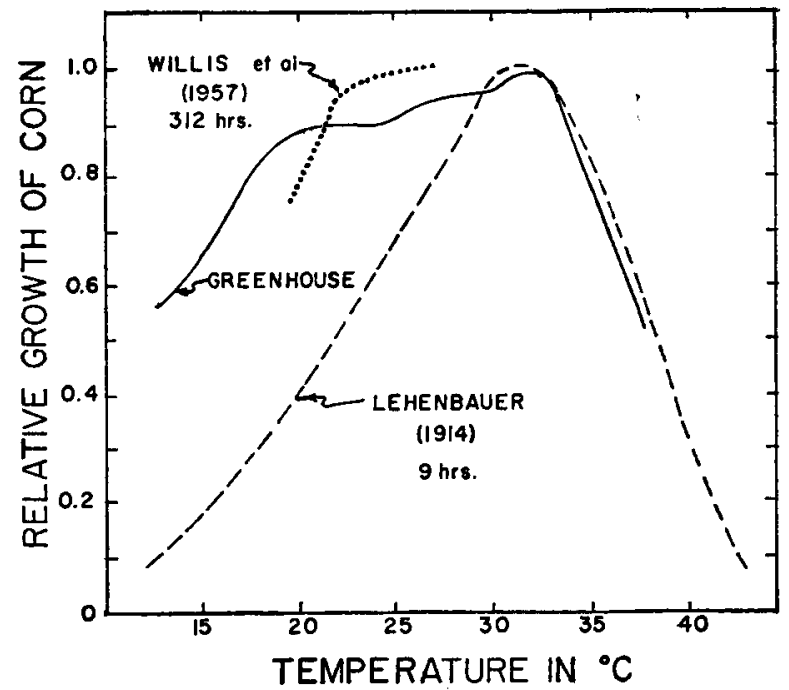

Fig. 4.

Relative growth of corn as affected by three different conditions of ambient root and shoot temperatures

in August, moisture was critically low in the soil on all treatments. Thus, in experiment II, soil moisture was probably more important than soil temperature in governing grain yields.

All crops exhibit a growth curve, as influenced by air and soil temperatures, which consists of a minimum below which growth will not proceed, followed by an increasing growth rate with increasing temperature up to an optimum, and then a decreasing growth rate to a point where growth ceases. The cardinal points vary with different crops. The data shown in FIGURE 4, taken from Allmaras et al. (1), show three growth-temperature curves for maize. The curve labeled LEHENBAUER (12) was determined for a 9 hour growth period in the near darkness when root and ambient temperatures were the same. The GreEnHOuse curve was determined where root temperatures were maintained at the indicated level and where the ambient temperature varied between about 27 and $30^{\circ} \mathrm{C}$ (1). Growth was observed from the seedling stage to 45 days later. The curve labeled WILlis et al. (18) was determined from leaf elongation in the field where the soil temperature at the $10 \mathrm{~cm}$ depth averaged at the indicated temperature and where the air temperature fluctuated. The GREenHouse and LeHENBAuER curves both suggest an optimum soil temperature for maize seedling growth at about 30 to $32^{\circ} \mathrm{C}$. The curve labeled WiLlis et al. was not carried over a large enough temperature span to determine an absolute optimum, but a $24^{\circ} \mathrm{C}$ optimum was suggested from other data (18). In the experiment by WiLLis et al. soil temperatures were measured arbitrarily at the $10 \mathrm{~cm}$ depth. The difference in the Greenhouse and Lehenbauer curves from 13 to $30^{\circ} \mathrm{C}$ is probably due to the much higher ambient than root temperatures in the GreENHOuse case, whereas ambient and root temperatures were the same in the LEHENBAUER case To extend the applicability of the previously described field experiments to other sections of eastern United States, an experiment to determine the relationship between maize growth and soil temperature was conducted at 9 locations over a 4 year period for a total of 23 location-years. The treatments consisted of all combinations of $6720 \mathrm{~kg}$ per ha of oat or wheat straw plowed under or left on the surface and 
adequate nitrogen fertilization (variable among location-years) or adequate nitrogen fertilization plus $112 \mathrm{~kg}$ per ha of nitrogen. The phosphorus and potassium fertilization was applied at each location-year as needed for adequate supply. Air temperature at the site and soil temperatures on the various treatments were recorded daily. Soil moisture and various plant growth indexes were measured at frequent intervals. The average reduction in the $10 \mathrm{~cm}$ soil temperature due to the mulch treatment was $1.25^{\circ} \mathrm{C}$ and did not vary greatly among locations. From the recorded data, Allmaras et al. (1) developed the relationship given in FIGURE 5. A similar relationship has been presented for a portion of this data by VAN WIJK et al. (17) and LARSON et al. (11).

The data in FIGURE 5 show that the relative dry matter production in maize at the nine widely different locations was essentially linearly related to the $10 \mathrm{~cm}$ soil temperature over the range from 15 to $27^{\circ} \mathrm{C}$. Above $27^{\circ} \mathrm{C}$ dry matter production was inversely related to soil temperature. The soil temperature values shown in FIGURE 5 were measured at the $10 \mathrm{~cm}$ depth and thus are of value for comparative purposes with temperatures in other experiments when measured in the same way. They may not represent an average soil temperature of the root zone. Thus the cardinal points cannot be compared directly with the cardinal points shown for the LeHENBauer and Greenhouse curves in Figure 4.

From the relationship shown in FIGURE 5 the effect of a change from the standard soil temperature (defined as the average $10 \mathrm{~cm}$ depth temperature in a bare soil with smooth microrelief) can be estimated. For example, if the average soil tem-

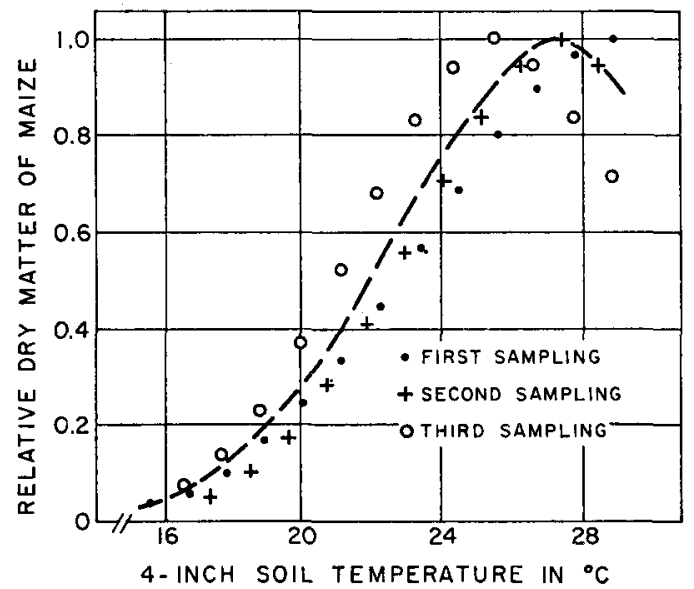

FIG. 5.

Relative yield of dry matter in young corn plants as affected by the average $10 \mathrm{~cm}$ soil temperature observed at three sampling dates

perature under standard conditions during approximately the first 2 months following planting is $18^{\circ} \mathrm{C}$ and a $1^{\circ} \mathrm{C}$ lowering is caused by a management practice, then a material reduction in the early growth of maize can be expected as compared with the growth under standard conditions. Soil temperatures of $18^{\circ} \mathrm{C}$ at the $10 \mathrm{~cm}$ depth are common during the early growth period in the maize growing areas of northern United States. On the other hand, if the standard soil temperature is $30^{\circ} \mathrm{C}$ and a $1^{\circ} \mathrm{C}$ reduction is created by a tillage practice, a material increase in maize growth during the early season may be expected. 
The relationship between soil temperature and maize grain production was not quantitatively established in the previously described experiments because soil moisture often limited growth during the latter part of the season. In the northern maize growing areas, however, where serious reductions in early growth occurred because of lowered soil temperature from mulching and where soil moisture was not limiting throughout the season, grain yield reduction usually occurred also. For example, in Iowa in 1958 and 1959 the ratio of maize grain yield on mulched to unmulched soil was .82 and .90 , respectively. The soil temperature during the first 60 days following planting averaged 18.8 and $19.2^{\circ} \mathrm{C}$ on unmulched soil and the ratio of early growth was .72 and .53 , respectively. In addition to reductions in grain yield, depressing the early maize growth rate is undesirable because the ratio of weed to maize growth rate may be increased, and, consequently, more maize plants may be covered with soil during mechanical weed control cultivation.

\section{Secondary Aggregate Size in the Seed Zone}

In the United States of America much progress has been made in reducing the number of operations needed to prepare a seedbed for row crops. However, with the reduced tillage systems, crop stands are sometimes unsatisfactory. Thus, much work has been done recently in an attempt to define the conditions around the seed necessary for good seedling emergence and growth. Most seedbed preparation methods include some means for mechanically reducing the size of the secondary aggregates ${ }^{3}$ in the seed row and for pressing the soil around the seed. Without a suitable secondary aggregate size the contact between soil and seed is insufficient to insure adequate transmittal of water from soil to seed, and the danger from excessive evaporation losses is increased. Thus, it would seem that the secondary aggregate size and bulk density of the soil in the seed zone would be good criteria by which to evaluate the soil conditions in the seed row.

Changing the aggregate size has a material influence on the total porosity and the size and total volume of the inter-aggregate (pores between aggregates) and intraaggregate pores (pores within aggregates). However, specifying the secondary aggregate size does not necessarily define the pore relationships. Fraser (6) has shown that the inter-component (aggregate) pore size and total inter-component porosity can vary considerably in single-, two-, and multi-component systems of regularly and irregularly shaped particles depending on the packing and the percentage and shape of the components.

In beds of soil aggregates, friction, adhesion, and bridging become of increasing importance because of the higher ratio of surface area to volume and mass. Thus generally as aggregate-size decreases, the total porosity increases and the size of the pores decreases. TAMBOLI ${ }^{4}$ has shown that, as secondary aggregate size decreased from 3.0 to $0.5 \mathrm{~mm}$ the total inter-aggregate porosity doubled.

The size relationships of the intra-aggregate pores differs with aggregate size. VoorHEES et al. (16) have shown that the volume of water retained per unit volume of air-dry aggregate at a given suction was negatively related to the diameter of the

3 Secondary aggregates are defined as the granules (including clods) that are relatively stable to breakdown when gently sieved in the dry state but are not necessarily stable when agitated in water. 4 Tamboli, P. M. : The influence of bulk density and aggregate size on soil moisture retention. Unpublished Ph.D. Thesis, Iowa State University Library, Ames, Iowa, USA. 
aggregate separates. The decreased volume of water retained with increasing aggregate size was directly associated with changes in apparent density of the aggregate.

Holmes et al. (7) found under artificial conditions that the relative evaporation rate from beds of aggregates of $2.5 \mathrm{~mm}, 25 \mathrm{~mm}$, and $50 \mathrm{~mm}$ in diameter was 1.0 , 30 , and 40 , respectively.

JoHNSON and TAYLOR (9) showed a relation between maize emergence and the size of the aggregate surrounding the seed. They suggested that 30 percent of the soil mass in the zone around the seed should be composed of secondary aggregates less than $2.5 \mathrm{~mm}$ in diameter in a clay soil in Ohio. Later, working in the laboratory on beds of uniform sized aggregates, JoHNson and Buchele (8) found that the drying rate increased and maize emergence decreased as the aggregate size increased from 1.2 to $6.7 \mathrm{~mm}$.

\section{Compaction of Soil Around the Seed}

Considerable work has been done on compaction of soil around seed for optimum germination and seedling growth, but the compacting pressures usually have not been related to the achieved bulk density. Sugar beet, maize and bean seedling emergence were compared after pressures from 35 to $700 \mathrm{~g}$ per $\mathrm{cm}^{2}$ were applied to the surface or at seed level (14). If moisture was adequate and crust strength not prohibitive, compaction at the surface above $35 \mathrm{~g}$ per $\mathrm{cm}^{2}$ was not beneficial and sometimes was harmful. If mechanical soil strength was high because of low moisture contents, the greater pressures reduced emergence.

Emergence of sugar beets, beans, and maize was generally superior when pressures from 35 to $700 \mathrm{~g}$ per $\mathrm{cm}^{2}$ were applied at seed level as compared to pressures on

the surface (14). Pressures applied at seed level provide good soil solution-seed contact for transmittal of water, and do not encourage formation of surface crusts. Small press wheels that pass over the seed prior to soil covering are now used on several commercial cotton and maize planters.

STOUT et al. (15) found that, initially seeds contained more water in compacted than in noncompacted soils but that at later times, the reverse was true. They believed the initial greater transmission to the seed in the compacted soil was due to better soil-solution-seed contact. At later times, however, transmission was slower presumably because of lower transmission rates through the compacted soil to the seed-soil-solution interface.

While compaction at seed level or at the surface can materially influence seed germination, the influence of compaction on bulk density is difficult to measure because of the short horizonal distances over which the effect takes place.

\section{Water Management}

In the central United States rainfall often occurs at rates more rapid than the water intake rate of the soil. For example, the 30 minute recurrent rate for 2, 5, 10 , and 25 years are approximately $3,4,4.5$, and $5 \mathrm{~cm}$, respectively. The highest rainfall rates usually occur in the spring when the tilled soil is devoid of vegetation or crop residue mulches. Tillage practices that provide conditions for rapid water intake and for temporary storage of water on the soil surface or in the tilled layer are needed to prevent water runoff. This reduces erosion and stores the moisture for use during the dry part of the summer. The soil zone between crop rows can be manipulated to achieve water management objectives. 


\section{Depression Storage}

During a rain or irrigation a soil surface with an uneven microrelief can store considerable water in the microdepressions on the soil surface for later intake into the soil. The potential storage capacity has been termed depression storage. A meter for measuring the soil microrelief created by tillage operations as an index of potential depression storage has been devised by Burwell, Allmaras and Amemiya (4). The meter is similar to one described by KuIPERs (10). If exactly on the contour, the deep furrows resulting from contour listing can store as much as $7.5 \mathrm{~cm}$ of rainfall on the surface and materially reduce runoff. Reduced tillage methods, if on the contour, probably have a potential storage for a 5.0 to $7.5 \mathrm{~cm}$ rain. A smooth soil surface such as is often prepared by conventional tillage practice can store less than $2.5 \mathrm{~cm}$ of water.

\section{Plow Layer Storage}

In the reduced tillage systems where plowing is the only tillage operation in the water management zone prior to emergence of the crop, the increased porosity created by plowing acts as a reservoir for temporary water storage during rainfall. The following example is typical of what occurs during tillage on many Brunizem and Gray-Brown Podzolic soils of the north central United States.

If a mineral soil with a solids volume fraction of 0.50 (bulk density $+1.32 \mathrm{~g} / \mathrm{cc}$ ) is loosened by plowing $20 \mathrm{~cm}$ deep to a solids volume fraction of 0.40 (bulk density of $1.06 \mathrm{~g} / \mathrm{cc}$ ) the thickness of the layer is increased from 20 to $25 \mathrm{~cm}$. The total amount of water that can be held at saturation in the initial $20 \mathrm{~cm}$ soil layer is $10.0 \mathrm{~cm}$; with the increased porosity resulting from plowing the total potential storage at saturation is $15.0 \mathrm{~cm}$. Thus $5 \mathrm{~cm}(15-10)$ of additional pore space has been added by plowing. The centimeters of air filled porosity in the plow depth at field capacity has been termed the plow layer storage.

Changing the volume fractions of air, water, and solids changes the initial volumetric moisture content and the suction-volumetric moisture content relationships, both important terms in theoretical infiltration equations (13).

The bulk density of the tilled layer of soil can be determined prior to tillage by means of undisturbed cores. Changes in bulk density in tilled soils throughout the season can be estimated through changes in surface elevation as measured by a point quadrant instrument (4).

1. Allmaras, R. R., W. C. Burrows and W. E. LARSON

2. Burrows, W. C.

3. Burrows, W. C., and W. E. LaRson

4. Burwell, R. E., R. R. Allmaras and M. AmemiYA

\section{I T ER A T U R E}

Early growth of corn as affected by management of soil temperature. Unpublished manuscript.

Characterization of soil temperature distribution from various tillage-induced microreliefs. Soil Sci. Soc. Am. Proc. (In press).

Effect of amount of mulch on soil temperature and early growth of corn. Agron. J. $54: 19-23.1962$.

A field measurement of total void volume and surface microrelief of soils. Soil Sci. Soc. Am. Proc. (In press). 
5. Duin, R. H. A. van

6. Fraser, H. J.

7. Holmes, J. W., E. L. Grea- The evaporation of water from bare soils with different tilths. CEN and C. G. GURR

8. Johnson, W. H., and W. F. Buchele

9. Johnson, W. H., and G. S. TAYLOR

10. KUIPERS, $\mathbf{H}$.

11. Larson, W. E., W. C. BurRows and W. O. WILLIS

12. Lehenbauer, P. A.

13. Phillip, J. R.

14. Stout, B. A., W. F. Buchele and F. W. SNYDER

15. Stout, B. A., F. W. SNYDER and W. F. Buchele

16. VoORHEES, W. B., R. R. Allmaras, M. AMEMIYA and P. M. TAMBOLI

17. WiJK, W. R. vaN, W. E. LARSON and W. C. Burrows

18. Willis, W. O., W. E. LarSON and D. KIRKHAM
Over de invloed van grondbewerking op het transport van warmte, lucht en water in de grond. Versl. Landbouwk. Onderz. No. 62.7. 1956.

Experimental study of the porosity and permeability of clastic sediments. Jour. Geol. $43: 910-1010.1935$.

Int. Soil Sci. Soc., Trans. 7 Cong. (1) 1 : 188-194. 1960.

Influence of soil granule size and compaction on rate of soil drying and emergence of corn. Trans. Am. Soc. Agr. Eng. 4 : 170-174. 1961.

Tillage treatments for corn on clay soils. Trans. Am. Soc, Agr. Eng. 3: 4-7, 10. 1960.

A reliefmeter for soil cultivation studies. Neth. J. Agr. Sci. 5: 255-262. 1957.

Soil temperature, soil moisture and corn growth as influenced by mulches of crop residues. Int. Soil Sci. Soc., Trans. 7 Cong. $1: 629-637.1960$.

Growth of maize seedlings in relation to temperature. Phy. siol. Res. 1 : 247-288. 1914.

The theory of infiltration $V$. The influence of the initial moisture content. Soil Sci. 84: 322-339. 1957.

Effect of soil compaction on seedling emergence under simulated field conditions. Agr. Eng. 42: 68-71, 87. 1961.

The effects of soil compaction on moisture absorption by sugar beet seeds. Quarterly Bul. Michigan Agr. Expt. Sta. 42 : 548-557. 1960.

Effect of aggregate size on moisture retention. Unpublished manuscript.

Soil temperature and the early growth of corn from mulched and unmulched soil. Soil Sci. Soc. Am. Proc. 23 : 428-434. 1959.

Corn growth as affected by soil temperature and mulch Agron. J. 49 : 323-328. 1957. 